DEPÓSITO LEGAL ZU2020000153

Esta publicación científica en formato digital

es continuidad de la revista impresa

ISSN 0041-8811

E-ISSN 2665-0428

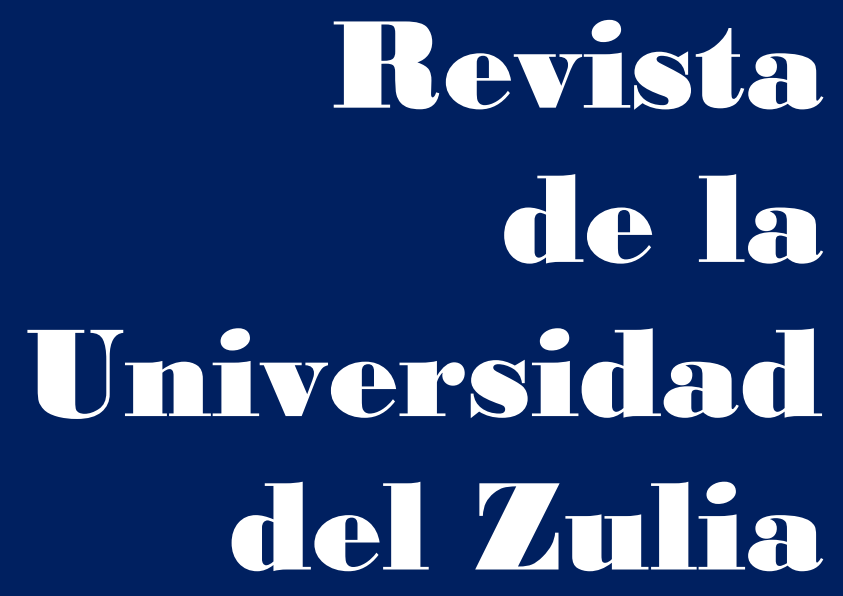

Fundada en 1947

por el Dr. Jesús Emrique Lossada

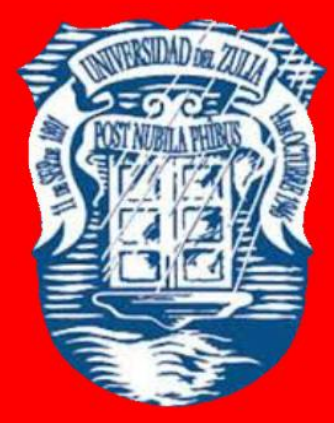

Ciencias

Sociales

y Arte

Año $12 \quad N^{\circ} 34$

Septiembre - Diciembre 2021

Tercera Época

Maracaibo-Veneruela 


\title{
Social and civil aspects of intellectual property regulation in Ukraine
}

\author{
Yevhen Leheza* \\ Anzhelika Pylypenko ** \\ Larysa Svystun *** \\ Oksana Zuieva $* * * *$ \\ Inna Yefimova *****
}

ABSTRACT The purpose of the research. They are considered relevant issues of the administrative and legal situation of subjects of special competence in relation to public administration in the field of intellectual property. Main content. A circle of specific subjects in the public administration system is determined. It identifies the role of subjects of special competence in the performance of the tasks of public administration in the field of intellectual property. The classification of subjects of special competence in the public administration is presented. Methodology: Analysis of documentary sources; the basis is the dialectical method of knowledge of the facts of social reality, on which the comparative formal and legal approaches are largely based. Conclusions. Conclusions are drawn on the place of subjects of special competence in relation to public administration in the field of intellectual property. Proposals are made on the need to improve existing legislation in Ukraine on intellectual property.

KEY WORDS: Civil law; copyright; intellectual property; private law.

* Professor at the Department of Administrative and Customs Law, University of Customs and Finance, Dnipro, Ukraine. ORCID ID: https:/orcid.org/0000-0001-9134-8499. Email: yevhenleheza@gmail.com

**Associate Professor, University of Customs and Finance, Dnipro, Ukraine. https://orcid.org/0000-0003-2592-7331. Email: angel.pyl.phd@gmail.com

***Associate Professor, University of Customs and Finance, Dnipro, Ukraine. https://orcid.org/0000-0003-2020-8354. Email: lara.svistun@gmail.com

****Candidate of Juridical Sciences, Associate Professor of the Department of Civil, Commercial and Environmental Law University of Customs and Finance, Dnipro, Ukraine, ORCID ID: https:/orcid.org/0000-0001-8054-1509. E-mail: oksana_zueva@i.ua

*****Candidate of Legal Sciences, Associate Professor Associate Professor of the Department of Criminal Law Disciplines and Law Enforcement of the University of Customs and Finance, Dnipro, Ukraine. https://orcid.org/0000-0003-4591-9734. E-mail: inka_vitaminka@i.ua 


\section{Aspectos social y civil de la regulación de propiedad intelectual en Ucrania}

RESUMEN

El propósito de la investigación. Se consideran cuestiones relevantes de la situación administrativa y jurídica de los sujetos de especial competencia en relación con la administración pública en el campo de la propiedad intelectual. Contenido principal. Se determina un círculo de materias específicas en el sistema de la administración pública. Se identifica el papel de los sujetos de especial competencia en el cumplimiento de las tareas de la administración pública en el ámbito de la propiedad intelectual. Se presenta la clasificación de materias de especial competencia en la administración pública. Metodología: Análisis de fuentes documentales; la base es el método dialéctico de conocimiento de los hechos de la realidad social, en el que se basan en gran medida los enfoques legales formales y legales comparados. Conclusiones. Se extraen conclusiones sobre el lugar de los sujetos de especial competencia en relación con la administración pública en el campo de la propiedad intelectual. Se formulan propuestas sobre la necesidad de mejorar la legislación vigente en Ucrania en materia de propiedad intelectual.

PALABRAS CLAVE: Derecho civil; derechos de autor; propiedad intelectual; Derecho privado.

\section{Introduction}

Issues of determination of the administrative and legal status remain today relevant in relation to a number of unresolved theoretical and practical issues in this sphere. And despite the intensity and a wide range of research devoted to various aspects of these problems, many issues in this field are still controversial. Meanwhile, the strength of the foundation for the innovative development model, its modernization, increase of competitiveness in the world socio-economic system depend on the resolution of the problem of creating an effective system of subjects of public administration in the field of intellectual property in Ukraine, with a clear definition of their administrative-legal status. And on this, in turn, - the prospects of creating jobs in new industries that are the face of the world economy of the XXI century - a knowledge-based economy.

A special place in the system of subjects of public administration in the sphere of intellectual property is occupied by state authorities with special powers in this field. Therefore, execution of mostly the same function of public administration is laid upon 
subjects of special (functional) competence, which includes authorities performing executive, supervisory, regulatory, and registration-authorization functions. These authorities provide for the implementation of state policy in a certain sphere, conduct management on issues of common interest to all or many sectors of the economy. Subjects of special competence in relation to public administration in the field of intellectual property should include those who, along with the performance of their main functions, also take part in public administration in the specified field. This group of subjects, depending on the peculiarities of their administrative-legal status, is divided into law-enforcement, regulatory, and judicial agencies.

\section{Literature review}

The judicial branch is endowed with its own powers on public administration in the field of intellectual property, and as a result of its reformation, there were principal changes (Petrenko etc, 2015). The fact is that over the last years, the idea of deepening the specialization of courts in intellectual property disputes was actively discussed in Ukraine, and in this regard two main points of view were formed: to create a separate specialized court (Koval, 2016). The State Judicial Administration, in agreement with the Supreme Council of Justice, by its order determined the number of judges in a new court - twenty-one posts. According to domestic experts, the very formation of a separate abovementioned court will contribute to solving the problem of delimitation of the jurisdiction of courts in the consideration of cases on issues of intellectual property and, accordingly, will ensure the application of the same and correct judicial practice in resolving relevant disputes. Also, the creation of this court will be aimed at building an effective intellectual property rights protection system taking into account international standards and, in addition, will improve the investment attractiveness of our state (Leheza etc, 2020).

Until recently, around ninety specialized courts were operating in the world. This trend is related, first of all, to the development of public relations in the field of intellectual property, as well as the entry of countries in which such courts exist, to the World Trade Organization (WTO) (although accession to it and the accession to the Agreement on TradeRelated Aspects of Intellectual Property Rights (TRIPS) do not oblige countries to set up relevant specialized courts, and many states make such decisions on their own initiative). The names of specialized courts on intellectual property are different in different countries 
of the world. For example, in Germany, this court is called the Federal Patent Court, while in Japan - the Intellectual Property High Court. However, the title is not the only aspect that distinguishes specialized courts in this area. First of all, it is about jurisdictional differences. Thus, intellectual property courts in Austria, the United Kingdom, Ireland, and Switzerland are based on the use of standards of the civil process, while there is a combination of standards of administrative and civil processes in Germany, and only administrative in Sweden (Kolesnikova etc, 2016).

The norms regarding the jurisdiction of the High Intellectual Property Court contain the newly revised Commercial Procedure Code of Ukraine (hereinafter referred to as the CPC of Ukraine). In accordance with paragraph 2 of Art. 20 of the CPC of Ukraine, the newly formed court will consider the case at first instance: in disputes concerning the rights to an invention, utility model, industrial design, trademark (mark for goods and services), commercial name, and other intellectual property rights, including the right of prior use; in disputes concerning registration, record of intellectual property rights, invalidation, extension of validity, previous cessation of patents, certificates, other acts that certify or on the basis of which such rights arise, or violate such rights or related legitimate interests; recognition of a trademark as well-known; in disputes concerning the authors' rights and related rights, including disputes over collective management of proprietary rights of the author and related rights; in disputes regarding the conclusion, modification, termination, and execution of an agreement on the disposal of intellectual property rights, commercial concessions; in disputes arising out of relations associated with the protection against unfair competition in relation to: the misuse of marks or goods of another manufacturer; copying the appearance of the product; collection, disclosure, and use of commercial secrets; appeal against decisions of the Antimonopoly Committee of Ukraine on issues specified by this item (Zaitseva, 2015).

Also, the High Intellectual Property Court will include the Appeals Chamber on Intellectual Property, which, according to paragraph 3 of Art. 25 of the CPC of Ukraine will review the decisions made by this court on appeal. Consequently, consideration of cases on intellectual property issues will be carried out in accordance with the rules of commercial court proceedings. At the same time, this will happen with certain peculiarities, in particular: the parties to the relevant disputes will be not only business entities (legal entities and 
individual entrepreneurs) but also ordinary individuals; state authorities and local selfgovernment bodies will also take part in disputes concerning the invalidation of acts of such bodies that violate intellectual property rights; collective consideration of cases is being introduced (Vatsyk, 2017).

\section{Materials and Method}

Research of materials and methods based on the analysis of documentary sources and regulatory legal acts of foreign countries. The dialectical method of cognizing the social reality facts is the basis on which the formal legal and rather-legal approaches are largely based. The formal-dogmatic method contributed to the development of the authors' explanation of the current state, problems, problems and practical role of legal technologies for the further development and improvement of intellectual property. The formal-legal method made it possible to suggest directions and types of use of legal technologies as perspectives of intellectual property.

\section{Results and discussion}

3.1. Administrative-legal status of regulatory authorities - subjects of public administration in the field of intellectual property

The main difference between the subjects of public administration that are a part of the group of regulatory actors from law enforcement bodies is that their defining function is the control function, which, as noted above, already belongs to secondary law enforcement functions. At the same time, the law-enforcement nature of the control function is connected primarily with the fact that the regulatory bodies, acting as an integral part of the state apparatus, act in the name of and on behalf of the state and exercise control over the observance of legality in one or another field of state activity. An essential feature of the activities of the controlling bodies and, in particular, those bodies operating in the field of public administration in the sphere of intellectual property is the fact that the scope of control activity and authority of the latter extends to objects regardless of their departmental subordination. That is, regardless of who owns, uses, or disposes of intellectual property rights, it can become subject to control by the controlling authority. Their number is quite significant, and the following can be attributed to the list of controlling agencies that carry out public administration in the field of intellectual property: the Antimonopoly Committee 
of Ukraine, the State Fiscal Service of Ukraine (hereinafter - SFSU), the State Service of Ukraine for Food Safety and Consumer Protection (hereinafter - SSUFSCP), Ukrainian Institute for Plant Variety Examination, State Service of Ukraine for Geodesy, Cartography and Cadastre (hereinafter - SSUGCC), Ministry of Health of Ukraine, Ministry of Culture of Ukraine, Ukrainian State Film Agency, Ministry of Ecology and Natural Resources of Ukraine, as well as State Property Fund of Ukraine (hereinafter - SPFU).

In particular, the Antimonopoly Committee of Ukraine has a significant influence on the activities of economic entities. Acting as a central executive body with a special status, it protects the interests of business entities from unfair competition related to the unlawful use of intellectual property objects in relation to the misuse of commercial designations, the unlawful use of goods by another manufacturer, and copying the appearance of the product. The Antimonopoly Committee of Ukraine exercises state control over the compliance with legislation on protection against unfair competition. In accordance with the Law of Ukraine «On Protection Against Unfair Competition», unfair competition is a way of violating the right of intellectual property, which is any action in a competition that is contrary to trade and other honest practices in economic activity (Official site of the Verkhovna Rada of Ukraine, 1996). The actions that are recognized as unfair competition and violate the right of intellectual property are: unlawful use of the business reputation of the business entity (use of the name, commercial (corporate) name, trademark (mark for goods and services), promotional materials, the registration of packaging of goods and periodicals, other marks without the permission (consent) of an entity that has previously started using them or similar marks in economic activities that led or may result in confusion with the activity of this entity), creation of obstacles to business entities in the process of competition (introduction into economic circulation under its mark of goods of another manufacturer by changing or removing the marks of the manufacturer without the permission of the authorized person, reproducing the appearance of the product of another entity and introducing it into economic circulation without a single indication of the manufacturer of a copy that may lead to confusion with the activity of another entity), and the achievement of unlawful competitive advantages and improper collection, disclosure, and use of commercial secrets.

Measures on public administration in the field of intellectual property in the process 
of foreign economic activity and prevention of movement across the customs border of Ukraine of counterfeit is used by the State Fiscal Service of Ukraine (SFSU) - an authority that implements state tax policy, state policy in the field of state customs affairs, state policy on administering a unified contribution for compulsory state social insurance, state policy in the field of combating offenses in the application of tax, customs legislation, as well as legislation on issues of payment of unified contribution. In the machinery of the SFSU, the aforementioned function is assigned to the Office for Organisation of Customs Control and Registration of the Customs Department, which includes the Division for the Protection of Intellectual Property Rights and Export Control. The SFSU, in accordance with its functions, ensures the keeping of the customs register of intellectual property, which, based on statements of owners of property rights to intellectual property, includes already more than 1.5 thousand objects. According to the European Union, 25 million products are falsified annually. With the development of technologies, counterfeits are being improved, therefore, the issue arises about setting up continuous training of customs officers, improving control facilities, and creating special units at the customs border to counteract counterfeit goods.

Countering offenses in the field of intellectual property is also a part of the functions of the State Fiscal Service of Ukraine (SFSU). In accordance with the Resolution of the Cabinet of Ministers of Ukraine on May 21, 2014, N ${ }^{\circ} 432$, the main tasks of the SFSU include the adoption of measures to protect intellectual property rights in the process of foreign economic activity, preventing the movement of counterfeit goods through the customs border of Ukraine (Official site of the Cabinet of Ministers of Ukraine, 2014). In particular, for import into the customs territory of Ukraine or export outside this territory of goods intended for industrial or other business activities, with violation of the intellectual property rights protected by law (Part 1 of Article 476 of the Customs Code of Ukraine), as well as in case of import into the customs territory of Ukraine or the export of counterfeit goods from this territory.

The list of grounds for suspending the customs clearance of goods, in respect of which the right-holder has not been filed an application to promote the protection of his/her property rights to the intellectual property, on the initiative of the body of incomes and fees, the Cabinet of Ministers of Ukraine, included: submission to the customs authority or to the State Customs Service of a statement of a person who, according to the law, owns property 
rights to an object of intellectual property rights not included in the customs register of objects of intellectual property rights or a person acting on his/her behalf within the limits of the given powers; received information on violation of intellectual property rights from law enforcement and controlling agencies, customs authorities of Ukraine and other countries, international organizations, whose competence includes protection of intellectual property rights; declaring a product with a trademark that is different from the trademark available in the customs register only by some elements and is similar to it in such a way that they can be confused (Official site of the Cabinet of Ministers of Ukraine, 2012). Thus, the activities of the SFSU in the area of countering the violation of intellectual property rights are aimed primarily at preventing the said offenses in the foreign economic activity of our country and stopping the movement of goods that were manufactured in violation of intellectual property rights through the customs border. In case of detection of violations of intellectual property rights in other spheres, the SFSU submits relevant materials to the law enforcement agencies as appropriate.

The next subject of public administration in the field of intellectual property of a special competence is the State Service of Ukraine for Food Safety and Consumer Protection (hereinafter-SSUFSCP), which is the central executive body whose activities are directed and coordinated by the Cabinet of Ministers of Ukraine through the Minister of Agrarian Policy and Food and which implements state policy, including in the field of protection of plant variety rights through the implementation of state supervision (control) in this area. The SSUFSCP, in accordance with the tasks entrusted to it, generalizes the practice of applying legislation on matters within its competence, develops proposals for the improvement of legislative instruments, acts of the President of Ukraine, the Cabinet of Ministers of Ukraine, laws and regulations of ministries and, in the prescribed manner, submits them to the Minister, who ensures the formation of state policy in the relevant field. In particular, in the field of plant variety rights protection, the SSUFSCP organizes and conducts state supervision (control) of: compliance with the requirements of the legislation on the protection of rights to plant varieties in the field of production, use, storage, sale, and reproduction of planting material of plant varieties; preservation of plant varieties, registration of licensing agreements for their use and payment of royalties; conducting primary seed growing by owners of proprietary rights of intellectual property and supporters 
of plant varieties; acquisition of rights to plant varieties and their registration; import of planting material (seeds) of unregistered plant varieties in Ukraine; the observance of the personal non-property right of authorship to the variety, the property right of the holder of the variety, the right of prior use and the right to renew the rights to a variety, the right to spread the variety in Ukraine, the rights of the author of the variety in the event of the owner's refusal from the property right to the variety, the order of removal from Ukraine of the planting material (seeds) of plant varieties containing an object of intellectual property, requirements of an agreement between the employer and the author of the variety for the payment of fair remuneration (Official site of the Cabinet of Ministers of Ukraine, 2015).

Effective public administration in the field of the protection of plant variety rights is impossible without the availability of appropriate examination facilities (due to the fact that crop production (along with animal husbandry) is traditionally considered as a leading branch of agriculture since the products of this industry form the basis for ensuring food security of the state), a leading role among which is played by the Ukrainian Institute for Plant Variety Examination, established in June 2002 through the reorganization of the State Centre for Certification, Identification, and Quality of Plant Varieties of the State Commission for Testing and Protection of Plant Varieties of the Ministry of Agrarian Policy and Food of Ukraine. The Institute is the basic research institution of the state system of protection of rights to plant varieties, which priority research areas are the implementation of projects in the field of protection of rights to plant varieties and conduct of state scientific and technical expertise of plant varieties as objects of intellectual property.

Separate powers regarding the public administration in the field of intellectual property are entrusted to the State Service of Ukraine for Geodesy, Cartography and Cadastre (SSUGCC), which, in accordance with the tasks entrusted to it: coordinates the activities related to the establishment, standardization, accounting, registration, use, and preservation of geographical names; organizes an appropriate examination of geographical names; provides for the creation and maintenance of the State Register of Geographical Names, controls the use and preservation of geographical names; defines stable geographic features on the territory of Ukraine; carries out in the established manner the definition of the boundaries of geographical areas, which are associated with special properties, certain qualities, and other characteristics of goods, and provides relevant conclusions (Official site 
of the Cabinet of Ministers of Ukraine, 2017).

Among the wide range of tasks entrusted to the Ministry of Health of Ukraine, it carries out the formation of state policy in the field of protection of intellectual property and access to medicines (Official site of the Cabinet of Ministers of Ukraine, 2015). This ministry is also a specially authorized body for the definition and control of special properties, certain qualities, and other characteristics of goods in relation to food, food raw materials, and mineral waters.

As the subject of public administration in the field of intellectual property of special competence, the Ministry of Culture of Ukraine (MCU) is responsible for the formation of state policy in the field of cinematography, culture, and arts, cultural heritage protection, export, import, and return of cultural property, state language policy, restoration and preservation of national memory, and also a specially authorized body for the determination and control of special properties, certain qualities, and other characteristics of products of folk artistic crafts. Although until recently, economic growth has been associated with technological and innovative development in technical fields (industrial society), with Ukraine's choice of the transition to the information society (post-industrial society), the sphere of culture goes to a qualitatively new level of development and communications. The provision of cultural services is increasingly turning into a «cultural industry» in which various goods and services are created and distributed. Culture encourages creativity and innovation. In this context, the important task of the Ministry of Culture should be the activation and strengthening of unique local traditions and customs, encouraging the process of revival and development of traditional Ukrainian folk crafts.

The Ministry of Culture exercises separate powers regarding public administration in the sphere of intellectual property through the Ukrainian State Film Agency subordinate to it. This body issues national certificates for the right to distribute and display films and, in carrying out this activity, takes measures to protect intellectual property rights, implement copyright and related rights.

The State Property Fund of Ukraine (SPFU), the central executive body with a special status, implements state policy in the field of privatization, lease, use, and alienation of state property, and the management of state-owned property (Official site of the Cabinet of Ministers of Ukraine, 2011). In the field of appraisal of property rights to objects of 
intellectual property right, the SPFU organizes training of appraisers, in particular, approves requirements to heads of entities of appraisal activity and appraisers, approves the composition and procedure of the examination committee for the training of appraisers in the direction «Estimation of integral property complexes of shares, securities, property rights and non-property assets, including assessment of rights to intellectual property objects), organizes their work, approves training programs and examinations.

Ministry of Ecology and Natural Resources of Ukraine, acting as the subject of public administration in the field of intellectual property of a special competence, is the main body in the system of central executive authorities in the formation and implementation of state policy in the field of environmental protection, environmental and, within its competence, biological, genetic, and radiation safety, waste management, including radioactive, pesticides, and agrochemicals (Leheza etc, 2021).

The Concept of the High Intellectual Property Court, however, contains a number of problematic issues. The first is the territorial remoteness of the High Intellectual Property Court since it will be located exclusively in the city of Kyiv, which naturally will cause the problem of access to this court by the majority of ordinary citizens of Ukraine. Secondly, there is a lack of ex parte proceedings in the CPC of Ukraine. In particular, the issue of the procedural mechanism of recognition of a trademark as well-known, which in any circumstances cannot be actionable, is not solved. The third problem is the problem of the professionalism of future judges - the Specialized Intellectual Property Court should unite people with both experience in this area and the corresponding special education (special knowledge). However, the legislator has for some reason decided that persons who may not have either the first one or the other can work in the High Specialized Court. This applies, first of all, to judges who have only a requirement for three years' service as a judge. In this case, such experience in the field of intellectual property or consideration of other disputes does not matter. And finally, fourthly, the negative aspect seems to be the lack of a specialist (advisor) in the court process, who has special knowledge of the practice of applying intellectual property law, as the new version of the CPC of Ukraine makes participation of a specialist in the process limited only by court assistance in the use of technical means. In this regard, according to a part of the scientists, it is expedient to introduce such a specialist, who could be involved in court in order to assist in establishing the actual circumstances of the 
case, providing oral advice or explanations (Zakharenko, 2014).

3.2. Administrative-legal status of law enforcement authorities - subjects of public administration in the field of intellectual property

Law enforcement authorities, which should include only those specifically created by the state to carry out any main law enforcement function under a clearly established law procedure, are endowed with important powers regarding public administration in the field of intellectual property. It is precisely this line of activity for the law enforcement authority to be the principal (main or priority) activity. Thus, based on the above, the system of law enforcement authorities of Ukraine may have the following form: Security Service of Ukraine, prosecution authorities, internal affairs bodies of Ukraine, State Fiscal Service of Ukraine, Department of State Guard of Ukraine, State Penitentiary Service of Ukraine, National Guard of Ukraine, and state border guard authorities. The analysis of the statutory enactments, which secure the legal status of these state law enforcement institutions, namely their tasks, functions, and powers, testifies that some of them (the Security Service of Ukraine, the bodies of the Prosecutor's Office of Ukraine, the bodies of internal affairs of Ukraine) are subjects of public administration in the sphere of intellectual property. The most important difference between their activities in relation to public administration in the field of intellectual property from the activities of other actors operating in this area is that it is associated not only with the organization of the protection of rights to intellectual property objects but with its active form - security (Leheza etc, 2018).

In accordance with the Law of Ukraine «On the Security Service of Ukraine) (Official site of the Verkhovna Rada of Ukraine. 1992), the security service participates in the development and implementation of measures to ensure the protection of state secrets (in particular, regarding secret inventions and utility models as objects of intellectual property, since in accordance with the Law of Ukraine «On Protection of Rights to Inventions and Utility Models) a secret invention or a secret utility model are objects containing information classified as state secrets), assistance in preserving commercial secrets (in the manner prescribed by the law of the SSU, assists enterprises, institutions, organizations, and entrepreneurs in preserving their commercial secrets, the disclosure of which may harm the vital interests of Ukraine, is responsible for the state policy on holographic protection of goods and documents, and carries out state control and coordination of activities in this 
area). In addition, while analysing the powers of the SSU, we also note that, although the counteraction to the intellectual property offenses does not fall within its direct competence, the SSU must provide assistance through available forces and means, including technical, to the National Police bodies, other law enforcement agencies in the fight against offenses, including violations in the field of intellectual property.

Important functions of the subject of public administration in the field of intellectual property are carried out by the of Public Prosecutor General's Office of Ukraine. According to Art. l of the Law of Ukraine «On Prosecutor's Office), the prosecutor's office, in the manner prescribed by this law, exercises the functions established by the Constitution of Ukraine in order to protect the rights and freedoms of man, the general interests of society and the state. In addition, Art. 2 of the Law of Ukraine «On Prosecutor's Office) establishes its main functions: maintenance of a state prosecution in court; representation of the interests of a citizen or state in court in cases specified by law; supervision over the observance of laws by the bodies conducting operative search activity, inquiry, pre-trial investigation; supervising the observance of laws during the execution of judicial decisions in criminal cases, as well as in the application of other coercive measures related to the restriction of personal freedom of citizens. Due to the fact that the illegal reproduction, replication, and distribution, including through the implementation of import-export operations, intellectual property objects violate, as a rule, the rights and legitimate interests of citizens, in accordance with Art. 23 of the above-mentioned law, the representation by the prosecutor of the interests of a citizen or a state in court is to carry out procedural and other actions aimed at protecting the interests of a citizen or a state. A significant role in stopping the illicit circulation of goods containing objects of intellectual property is played by the interaction between the departments of the customs service and the prosecutor's office of Ukraine.

DEPNPU was formed according to the order of the National Police of Ukraine. Among the functions of the DEPNPU, the use of anti-crime measures in state authorities, property rights, intellectual property, related to counterfeiting, and also the provision of compensation for losses caused by these crimes, are separately identified. Similar tasks and functions are assigned to all the administrations (departments) of the DEPNPU at the local level. Thus, counteraction to crimes in the field of intellectual property is one of the main functions of the DEPNPU but this does not affect the structure and specialization of its employees since the 
current structure of the DEPNPU does not provide for separate departments for combating crimes in the field of intellectual property, which usually significantly reduces the effectiveness of activities in this area. In practice, operational cases concerning crimes in the field of intellectual property are transferred for the development to one of the employees of departments of economic protection at the local level, however, as specialists note, there are few such cases for today.

Another division of the National Police of Ukraine, which directly deals with counteracting crimes against intellectual property, is the DCNPU. It was created in accordance with the order of the National Police of Ukraine. The DCNPU includes the Office for the Prevention of Crimes in the Sphere of Intellectual Property and Economic Activities (OPCSIPEA), which is managed by the Deputy Head of the DCNPU - the head of the OPCSIPEA. The OPCSIPEA's structure includes three departments: counteraction to crimes in the sphere of electronic commerce, counteraction to crimes in the sphere of circulation of illegal content and telecommunications, and counteraction to crimes in the sphere of payment systems. Accordingly, the counteraction to crimes against intellectual property related to the use of computer technologies is a priority task of the DCNPU. Information reports, presented on the official site of the DCNPU, confirm the effectiveness of the measures applied in the field of counteraction to crimes against intellectual property. Thus, according to the report of the DCNPU as of April 30, 2016, the detection of the clandestine manufacture of counterfeit copies of household chemicals, trademarks as Ariel, Tide, Head $\&$ Shoulders, Fairy, and Vanish was revealed in Lutsk. And the investigative police unit in the Rivne region opened a criminal proceeding under Art. 229 of the Criminal Code of Ukraine, within the framework of which there were established persons involved in the organization of the said criminal offense, the workers who were engaged in the packaging of counterfeit, as well as customers, who subsequently realized this counterfeit to citizens (Cyber police exposed in Lutsk underground production of household chemicals brands "Ariel", "Tide", "Head \& Shoulders", "Fairy" and "Vanish": report of the Cyberpolice Department of the National Police of Ukraine, 2016). Of course, the creation of a special department in the structure of the National Police of Ukraine to counteract crimes against intellectual property on the Internet should be considered positive and very relevant, however, it should also be noted that the activities of these units are more related to the 
stoppage of crimes in the specified area since the specifics of the latter is such that they are most often manifested by the consequences. Public coverage of the positive experience of countering cybercrimes related to the violation of intellectual property rights certainly has a certain preventive effect on persons who are prone to commit crimes in the field of intellectual property, but at the same time, in our opinion, the staff of the DCNPU should conduct purposeful development and carry out measures for the prevention of cybercrime against intellectual property, committed with the help of computer technologies.

The Ministry regularly conducts such operational and preventive measures as the operation «Intelligence», operation «Pirates», etc., on the development of intellectual property market subjects, during which one of the priority areas of work is defined as counteraction to the sales and the manufacture of counterfeit products using signs for goods and services of well-known Ukrainian and foreign manufacturers, as well as the fight against Internet piracy (Vyazmikin, 2016).

\section{Conclusions}

The system of subjects of public administration in the field of intellectual property is based on the generally acknowledged theory of state administration of their division into bodies of general, sectoral, and special competence. The basis of this classification is the scope and nature of competences in relation to objects of intellectual property, subjects of intellectual property rights, and functions of their public administration. Subjects whose competence includes the exercise of all functions related to public administration in the field of intellectual property in one or another volume, regardless of the type of the object of intellectual property and the subjects of their use, are bodies of general competence. They, along with sectoral and special actors, solve other issues of socio-economic development of the state.

The bodies of special competence ensure implementation of the state policy in one or several spheres by providing administrative services, state supervision (control), a generalization of the practice of application of legislation, development of proposals for the improvement of legislative acts. Executive authorities and their officials, as well as in a number of cases other entities, which are endowed with state powers that allow the latter to exercise regulatory influence on social relations, as well as the participants in these relations 
with the aim of organizing the lawful possession, use, and disposal of intellectual property rights, should be considered as subjects of special competence regarding public administration in the field of intellectual property. And the determination of their administrative and legal status will allow creating a reliable system of legal protection of the results of the intellectual creative activity.

Consequently, today the formation and start of work of the High Intellectual Property Court contain many unresolved issues of both procedural and organizational nature, which deepens the already complex task of the functioning of such a judicial branch in the judicial system of Ukraine.

Thus, public administration activities in the field of intellectual property are one of the functions of the SSU, the Prosecutor's Office, and the bodies of internal affairs within their competence as defined by law. That is, law enforcement agencies of Ukraine act as one of the subjects of public administration in the field of intellectual property. The necessity of attracting the latter to the mechanism of public administration of the mentioned sphere is explained by the widespread occurrence of cases of illegal, even criminal, violation of intellectual property rights, which requires the presence of a power mechanism for the prevention and stoppage of such violations.

\section{References}

Cyber police exposed in Lutsk underground production of household chemicals brands "Ariel", "Tide", "Head \& Shoulders", "Fairy" and "Vanish": report of the Cyberpolice Department of the National Police of Ukraine (2016). National Police of Ukraine. URL: https://www.cybercrime.gov.ua/16-novosti/73-kiberpolitsiya-viluchila-falsifikovanij-tovarprocter-gamble-na-ponad-miljon-griven-fotołnews.

Kolesnikova, Maria, Piddubna, Marina. (2016). Enforcement of international arbitration decisions in the field of intellectual property: the experience of Ukraine and European countries. Legal horizons. Vol. 2. Pp. 158-162.

Koval, Irina Fedorovna. (2016). Regarding the legal status of the Supreme Court on intellectual property issues. Theory and practice of intellectual property. Vol. 5. Pp. 39-44.

Leheza, Y., Tiutchenko, S., Stanina, O., Shatrava , S., \& Rezanov , S. (2021). Uso y protección del suelo: regulación legal y experiencia extranjera. Revista De La Universidad Del Zulia, 12(33), 70-81. https://doi.org/10.46925//rdluz.33.06 
Leheza Ye., Filipenko T., Sokolenko O., Darahan V., Kucherenko O. (2020). Ensuring Human Rights in Ukraine: Problematic Issues and Ways of their Solution in the Social and Legal Sphere. Cuestiones Politicas, 37(64), 124-136.. https://doi.org/10.46398/cuestpol.3764.10

Leheza, Yevhen, Savielieva, Maryna, Dzhafarova, Olena. (2018). Structural and legal analysis of scientific activity regulation in developed countries. Baltic journal of economic studies. Vol. 4 (3), pp. 147-157. Https://doi.org/10.30525/2256-0742/2018-4-3-147-157. https://doi.org/10.30525/2256-0742/2018-4-3-147-157

Official site of the Cabinet of Ministers of Ukraine (2015, March 25). On approval of the Regulation on the Ministry of Health of Ukraine: Resolution of the Cabinet of Ministers of Ukraine. URL: http://zakon.rada.gov.ua/go/267-2015-p.

Official site of the Cabinet of Ministers of Ukraine (2012, May). On approval of the list of grounds for suspension of customs clearance of goods in respect of which the right holder has not filed an application for assistance in protecting his property rights to intellectual property, at the initiative of the customs authority: Resolution of the Cabinet of Ministers of Ukraine. URL: http: //zakon4.rada.gov.ua/laws/show/432-2012-\%D0\%BF.

Official site of the Cabinet of Ministers of Ukraine (2014, May). About the State Fiscal Service of Ukraine: Resolution of the Cabinet of Ministers of Ukraine. URL: http://zakon.rada.gov.ua/go/236-2014-p.

Official site of the President of Ukraine (2017, September). On the establishment of the Supreme Court of Intellectual Property: Decree of the President of Ukraine. URL: http://zakon.rada.gov.ua/laws/show/299/2017.

Official site of the Verkhovna Rada of Ukraine (1996, July). On protection against unfair competition: Law of Ukraine. URL: https:/www.zakon.rada.gov.ua/go/236/96-vr.

Official site of the Verkhovna Rada of Ukraine (1992, March). On the Security Service of Ukraine: Law of Ukraine. URL: http://www.zakon.rada.gov.ua/go/2229-12.

Official site of the Verkhovna Rada of Ukraine (2011, December). About the State Property Fund of Ukraine: Law of Ukraine. URL: http://zakon.rada.gov.ua/laws/show/4107-17.

Petrenko, Vitaliy, Levitsky, Vyacheslav (2015). Improving the system of judicial protection of intellectual property rights. Theory and practice of intellectual property. Vol. 1. Pp. 64-70.

Vatsyk, Yuriy (2017). Problematic issues of judicial protection of intellectual property rights in civil proceedings of Ukraine. International scientific journal "Internauka". Vol. 17 (2). Pp. $75-77$.

Vyazmikin, Serhiy (2016). Tasks and powers of the Department of Economic Protection of the National Police of Ukraine. Legal Journal of the National Academy of Internal Affairs. Vol 1. Pp. 133-140. 
REVISTA DE LA UNIVERSIDAD DEL ZULIA. 3é época. Año 12 N 34, 2021

Yevhen Leheza // Social and civil aspect of intellectual property regulation in Ukraine, 206-223

DOI: http://dx.doi.org/10.46925//rdluz.34.13

Zaitseva, Anna (2015). Problems of determining the jurisdiction of courts in the field of protection of intellectual property rights to trademarks for goods and services. Theory and practice of intellectual property. Vol. 3. Pp. 28-35.

Zakharenko, Maxim (2014). Specialized Court for Intellectual Property Cases in Ukraine: Error or Necessity? Legal Bulletin. Vol 3. Pp. 201-204. 